\title{
THE LEGAL IN/SECURITY OF TEMPORARY Migrant Agricultural WorK: CASE STUdies FROM CANADA AND AUSTRALIA
}

\section{ANDREW NEWMAN ${ }^{*}$}

Despite differing labour law systems and program structures, temporary migrant agricultural workers under the Canadian Seasonal Agricultural Worker Program and Australian Seasonal Worker Program often possess minimal security of employment rights and protections, despite potentially lengthy periods of consecutive seasonal service to the same employer. Such lesser rights and protections are partly due to the central role played by continuity of service in determining the length of reasonable notice periods and the strength of unfair dismissal protections and stand-down/recall rights. Although it is often presumed that the temporary duration of the seasonal work visa necessarily severs the legal continuity of the employment relationship, such is not the case. This article argues that security of employment rights and protections can be re-conceptualised to recognise non-continuous seasonal service within the current parameters of a fixed-term work visa. In both Canada and Australia this could be accomplished through contractual or collective agreement terms or through the amendment of labour law legislation. Such reforms would recognise a form of unpaid 'migrant worker leave', whereby the legal continuity of employment would be preserved despite periods of mandatory repatriation, thus allowing accrual of security of employment rights and protections.

\section{INTRODUCTION}

Both Australian and Canadian labour law systems recognise that notice of termination requirements, unfair dismissal protections and recall/stand-down rights are key modes of legally regulating security of employment. Both labour law systems also recognise that the accrual of continuous service is the primary method by which employees move along a continuum towards

\footnotetext{
* Barrister, Victorian Bar; Member, Ontario Bar; PhD Candidate, Centre of Employment and Labour Relations Law, Melbourne Law School, The University of Melbourne. The author gratefully acknowledges the generous support of a Julian Small Foundation Research Grant (2011) in funding the research conducted in this article.
} 
increasing rights and protections. ${ }^{1}$ However, the default form of employment relationship with respect to temporary migrant agricultural workers in both countries is a fixed-term seasonal contract. Such contracts frequently prevent the accrual of continuous service, thus limiting the rights and protections available to temporary migrant workers. ${ }^{2}$ This limitation occurs regardless of the duration of such workers' service to the same employer over the course of multiple seasonal work visas. ${ }^{3}$

However, this default labour law setting is based on a legal fiction. In both countries, it is presupposed that the migration law parameters of the Australian Seasonal Worker Program ('ASWP') and the Canadian Seasonal Agricultural Worker Program ('CSAWP') necessitate the imposition of a fixed-term seasonal contract. This article will argue that although the combined effect of migration and labour law currently disadvantages temporary migrant workers in this way, this need not be the case. The labour law systems of both countries are sufficiently flexible to permit the recognition of a form of migrant worker leave. This leave would act to protect the legal continuity of employment despite seasonal lay-off and repatriation and thus facilitate the accrual of security of employment rights and protections. Migrant worker leave could be recognised through a range of labour law mechanisms, including through collective bargaining, adoption of standard form clauses in individual contracts and/or statutory reform of employment standards. Recognising migrant worker leave through these mechanisms would represent a fundamental departure from current practice. The potential for such reforms exists notwithstanding the current seasonal parameters of the temporary work visa prescribed by the CSAWP and ASWP. Such reforms would build upon tentative measures that have already been taken in both Canada and Australia to de-couple the accrual of labour law rights and entitlements from the accrual of continuous service. This article is composed of four main parts. The first (under heading II below) will provide a general introduction to the issue of legally precarious employment in the agricultural sector. The second (under heading III below) will discuss the relevant conceptual background to the problem. The following part will engage in an examination of the labour law regulation of security of employment in both Canada and Australia. In particular, it will consider how CSAWP and ASWP workers are generally disadvantaged with respect to notice of termination, unfair dismissal and employment standards protection by virtue of their inability to accrue continuity of employment. The last part (under heading $\mathrm{V}$ below) will provide concluding thoughts and briefly outline potential options for recognising continuity of employment through a form of

\footnotetext{
${ }^{1}$ See discussion below in Part III A.

${ }^{2}$ See discussion below in Part III C and D.

${ }^{3}$ See discussion below in Part III B.
} 
migrant worker leave enshrined in standard form contracts, collective bargaining agreements and statute.

\section{THE LEgal Precariousness OF Temporary MigRant AgRICULTURAL WORK}

Legally precarious employment has grown markedly in many developed economies in recent decades, including Canada and Australia. ${ }^{4}$ The rise of legally precarious employment has been viewed as a by-product of the drive towards so-called 'flexible' labour markets at both the domestic and international levels. ${ }^{5}$ The term 'flexibility' is often a euphemism for either reducing the level of existing worker protections or permitting employers to exploit gaps in the regulatory framework. ${ }^{6}$ In part as a result of this drive toward flexible markets, a growing inequality has developed in international labour migration law. In certain sectors (such as the resources, science, management and health sectors) of developed economies, employers actively compete in an international labour market to hire well-paid, formally skilled workers who are frequently offered a fast track to permanent residency. By contrast, unskilled agricultural workers from developing countries are far less likely to obtain entrance via the general migration law channels due to their inability to satisfy migration law systems weighted towards attracting formally skilled migrants. ${ }^{7}$ Targeted industry-based temporary labour

\footnotetext{
${ }^{4}$ See Rosemary Owens, Joellen Riley and Jill Murray, The Law of Work (Oxford University Press, $2^{\text {nd }}$ ed, 2011) 8; Judy Fudge and Rosemary Owens, 'Precarious Work, Women and the New Economy: The Challenges to Legal Norms' in Judy Fudge and Rosemary Owens, Precarious Work, Women and the New Economy: The Challenges to Legal Norms (Hart Publishing, 2006) 3, 10-12; Judy Fudge, 'Precarious Employment in Australia and Canada: The Road to Labour Law Reform’ (2006) 19 Australian Journal of Labour Law 105, 105-6, 109, 117; Anthony O’Donnell, “'Non-Standard” Workers in Australia: Counts and Controversies' (2004) 17 Australian Journal of Labour Law 89, 89-90; Breen Creighton, 'Employment Security and Atypical Work in Australia' (1995) 16(3) Comparative Labor Law and Policy Journal 285, 285.

${ }_{6}^{5}$ Fudge and Owens, above $\mathrm{n} 4$.

${ }^{6}$ Sandra Fredman, 'Precarious Norms for Precarious Workers' in Judy Fudge and Rosemary Owens, Precarious Work, Women, and the New Economy: The Challenges to Legal Norms (Hart Publishing, 2006) 177; Rosemary Owens, 'Engendering Flexibility in a World of Precarious Work' in Judy Fudge and Rosemary Owens, Precarious Work, Women and the New Economy: The Challenges to Legal Norms (Hart Publishing, 2006) 329, 337-40.

${ }^{7}$ Owens, Riley and Murray, above n 4, 43-4; Stéphanie Bernstein, 'The Regulation of Paid Home Care Work in the Home in Quebec: From Hearth to Global Market Place' in Judy Fudge and Rosemary Owens, Precarious Work, Women and the New Economy: The Challenges to Legal Norms (Hart Publishing, 2006) 223, 238; Mary Crock and Kerry Lyon, 'Nation Skilling: Migration, Labour and the Law' (Working Paper No 11, Asia Pacific Migration Research Network, 2002).
} 
migration programs therefore often represent the primary means by which unskilled foreign workers legally obtain restricted access to developed world labour markets. In 'triple D' (dirty, degrading and dangerous) sectors such as agriculture, often referred to as the bargain basement of globalisation, ${ }^{8}$ such programs have proliferated across the developed world. This growth in temporary migrant labour programs in Canada and Australia has been partly necessitated by the movement of local unskilled workers away from less desired employment towards highly paid resource sector work. ${ }^{9}$ The rise of unskilled temporary labour migration has been characterised by scholars of legally precarious work as part of a drive towards 'numerical flexibility'. ${ }^{10}$ Participating employers are provided with access to a vast supply of unskilled workers available on the global labour market. Such workers may be hired during peak periods of demand and repatriated to their country of origin until further required, with little or no accrual of labour law rights and protections. ${ }^{11}$ Unskilled temporary migrant worker programs are therefore frequently characterised as an increasingly prominent manifestation of legally precarious work, ${ }^{12}$ despite the professed objectives of governments to protect decent terms and conditions of employment. ${ }^{13}$

\footnotetext{
${ }^{8}$ International Labour Conference, Towards a Fair Deal for Migrant Workers in the Global Economy, Report VI, 92 ${ }^{\text {nd }}$ sess (1-17 June 2004), 45 [138].

${ }^{9}$ Fudge and Owens, above n 4, 8.

${ }^{10}$ Fredman, above n 6, 177.

${ }^{11}$ Joanne Conaghan, 'Time to Dream? Flexibility, Families and the Regulation of Working Time' in Judy Fudge and Rosemary Owens, Precarious Work, Women and the New Economy: The Challenges to Legal Norms (Hart Publishing, 2006) 101, 115-16.

${ }^{12}$ Bernstein, above n 7; Judy Fudge and Fiona MacPhail, 'The Temporary Foreign Worker Program in Canada: Low-Skilled Workers as an Extreme Form of Flexible Labour' (2009) 31(1) Comparative Labor Law and Policy Journal 5, 38; Judy Fudge, 'Global Care Chains, Domestic Work and Conundrum of Jurisdiction: Decent Work for Domestic Workers in Canada' (2011) 23(1) Canadian Journal of Women and the Law 235; Janet McLaughlin and Jenna Hennebry, 'Pathways to Precarity: Structural Vulnerabilities and Lived Consequences in the Everyday Lives of Migrant Farmworkers in Canada' (Paper presented at Producing and Negotiating Precarious Migratory Status in Canada, York University, Toronto, 16 September 2010); Luin Goldring, Carolina Berinsteig and Judith K Bernhard, 'Institutionalizing Precarious Status in Canada' (2009) 13(3) Citizenship Studies 239; Paula J Kinoshita and Delphine Nakache, The Canadian Temporary Foreign Worker Program: Do Short-Term Economic Needs Prevail over Human Rights Concerns (13 May 2010) Institute for Research on Public Policy <http://www.irpp.org/en/research/diversity-immigration-and-integration/new -research-article-3/>; Kerry Preibisch, 'Pick-Your-Own Labor: Migrant Workers and Flexibility in Canadian Agriculture’ (2010) 44(2) International Migration Review 404; Kerry L Preibisch and Evelyn Encalada Grez, 'The Other Side of el Otro Lado: Mexican Migrant Women and Labor Flexibility in Canadian Agriculture' (2010) 35(2) Signs: Journal of Women in Culture and Society 289.

${ }^{13}$ Owens, Riley and Murray, above n 4, 44-5.
} 
With respect to the choice of the term 'precarious' employment, it is worth noting that other terms such as 'non-standard', 'atypical', 'insecure' and 'contingent' employment have also been used in the literature to reflect the same or similar concepts. ${ }^{14}$ A preference for one term over another depends in part upon local context and usage. ${ }^{15}$ The academic literature does not adopt a consistent definition of legally precarious work across all countries, sectors and groups of workers ${ }^{16}$ but notes that it takes many frequently overlapping forms, such as: fixed-term, part-time or casual work, self-employment, work as an independent contractor, labour hire, on-call, home or agency work. ${ }^{17}$

Each of these forms of legally precarious work has its origins in multiple sources of labour law regulation. ${ }^{18}$ Legal scholars in the field have therefore analysed the problem of legal precariousness through a doctrinal consideration of the following main sources of law that regulate it: (i) the individual contract of employment; ${ }^{19}$ (ii) collective regulation, including awards and collective agreements; ${ }^{20}$ (iii) employment standards legislation; ${ }^{21}$ (iv) anti-discrimination law; ${ }^{22}$ (v) unfair dismissal legislation; ${ }^{23}$ and (vi) labour relations legislation governing collective bargaining rights. ${ }^{24}$

14 Judy Fudge, 'Beyond Vulnerable Workers: Towards a New Standard Employment Relationship’ (2005) 12 Canadian Labour and Employment Law Journal 151, 156.

${ }^{15}$ Ibid 156-7.

${ }^{16}$ Fudge and Owens, above n 4, 10.

${ }^{17}$ Ibid 12.

${ }^{18}$ This article will refer to 'labour law' in the Australian sense, as encompassing both collective and individual aspects of the legal regulation of the employment relationship. The North American convention, by contrast, is to delineate between 'employment law' and 'labour law'. The former refers to the legal regulation of the relationship between non-unionised employees and their employers. The latter refers to the legal regulation of the relationship between unionised workers and their employers by means of collective bargaining law and grievance arbitration.

19 O'Donnell, above n 4, 116; Claire Kirkpatrick, 'Gender and the Legal Regulation of Employment Breaks' in Judy Fudge and Rosemary Owens, Precarious Work, Women and the New Economy: The Challenges to Legal Norms (Hart Publishing, 2006) 153, 161-74.

${ }^{20}$ See, eg, Judy Fudge, 'The Road to Labour Law Reform', above n 4, 107, 111-2. See also Bernard Adell, 'Resisting Lower Terms for Imported Workers: Laval-Inspired Reflections on the Canadian Law' (2011) 32(4) Labor Law and Policy Journal 1023. For an Australian perspective, see, eg, Rosemary Hunter, 'The Legal Production of Work' in Judy Fudge and Rosemary Owens, Precarious Work, Women and the New Economy: The Challenges to Legal Norms (Hart Publishing , 2006) 283, 290-5.

${ }^{21}$ See, eg, Kirkpatrick, above n 19. See also Gillian Barnett, 'Employment Standards for NonStandard Employment: A Legislative Framework for Agency Work in Canada' (2008) 13 Appeal 74.

${ }^{22}$ See, eg, Adell, above n 20, 1048-53. See also Katerine V M Stone, 'The New Face of Employment Discrimination' in Judy Fudge and Rosemary Owens, Precarious Work, Women and the New Economy: The Challenges to Legal Norms (Hart Publishing, 2006) 243. 
Each form of legal regulation has been considered as providing a source of legal precariousness, usually due to the fact that the protective thrust of the regulation continues to privilege the standard employment relationship ('SER') over other forms of work. The SER, which is frequently defined in the literature as an ongoing, full-time employment relationship with a single employer $^{25}$ is generally characterised by greater legal rights and protections, including those pertaining to security of employment.

However, despite acting as a source of legal precariousness, labour law may also be structured so as to expand the scope of its protective coverage and close gaps in the regulatory network of rights and protections, thereby also acting as a vehicle through which to reduce legal precariousness. ${ }^{26}$

Just as the legal forms of precariousness are many, so too are the frequently overlapping and mutually reinforcing indices of the employment relationship which define it. As noted by Owens, Riley and Murray, the Secure Employment Test Case $^{27}$ in Australia demonstrated that legally precarious workers with insecure employment also experience a heightened incidence of other workplace risks including:

a greater chance of non-compliance with occupational health and safety standards; poor wages and conditions of work that did not meet basic award standards; and less access to training and skills development, and hence to career development. The repercussions of this then spilled over into private life: the uncertainties meant, for instance, that non-standard workers had more limited access to finance. ${ }^{28}$

Lack of employment security is therefore one important attribute of legal precariousness and often associated with other attributes, such as low wages, a

\footnotetext{
${ }^{23}$ Hunter, above n 20, 296.

${ }^{24}$ Richard Mitchell, David Taft and Anthony Forsyth, 'Research Report: Assessing the Impact of Employment Legislation: The Coalition Government's Labour Law Program 1996-2007' (2010) 23(4) Australian Journal of Labour Law 274, 294-8; Eric Tucker, “"Great Expectations” Defeated?: The Trajectory of Collective Bargaining Regimes in Canada and the United States Post-NAFTA' (2004) 26(1) Comparative Labor Law and Policy Journal 97, 148-50; Judy Fudge, 'A Canadian Perspective on the Scope of Employment Standards, Labor Rights and Social Protection: The Good, the Bad, and the Ugly' (2010) 31(2) Comparative Labor Law and Policy Journal 253, 258-60.

${ }^{25}$ John Howe, 'The Broad Idea of Labour Law: Industrial Policy, Labour Market Regulation, and Decent Work' in Guy Davidov and Brian Langille (ed), The Idea of Labour Law (Oxford Univeristy Press, 2011) 297, 299.

${ }^{26}$ Owens, above n 6, 340-52; Stone, above n 22, 259-63.

27 (2006) 150 IR 1.

${ }^{28}$ Owens, Riley and Murray, above n 4, 479.
} 
low incidence of collective bargaining, low levels of trade union membership and little control over working conditions or environment.

As to the definition of security of employment, it is itself a wide concept, which includes the legal rights and protections governing the termination of employment. Gerry Rodgers and Janine Rodgers identified four dimensions to security of employment, including one of particular relevance to this article: 'the extent of legal protections applicable to workers' ${ }^{29}$ Building upon the work of Gerry Rodgers and Janine Rodgers, Australian scholars John Burgess and Iain Campbell described eight forms of insecurity, noting that one key aspect of insecurity exists when workers can be dismissed or laid off or put on shorter time without difficulty. ${ }^{30}$

As this overview may suggest, migration law in particular plays a pivotal role in constituting the labour market in which labour law operates. ${ }^{31}$ Scholars in the field have noted that, though temporary migrant workers may share various attributes of vulnerability with local workers, they face additional factors of vulnerability which informs the particular manifestation of their legal precariousness. ${ }^{32}$ In the specific context of Ontario, Canada, Faraday argues that the four categories of low-skill temporary migrant workers present in the province often experience insecure employment, which is constructed

${ }^{29}$ Gerry Rodgers, 'Precarious Work in Western Europe: The State of the Debate' in Gerry Rodgers and Janine Rodgers (eds), Precarious Jobs in Labour Market Regulation: The Growth of Atypical Employment in Western Europe (International Labour Organization, International Institute of Labour Studies, 1989) 1, 3.

30 John Burgess and Iain Campbell, 'The Nature and Dimensions of Precarious Employment in Australia’ (1998) 8(3) Labour and Industry 5, 11.

${ }^{31}$ Fudge and MacPhail, above n 12, 6-7, 14-15, 38; Fudge, 'Global Care Chains', above n 12, 243; Crock and Lyon, above n 7; Mary Crock and Leah Friedman, 'Immigration Control and Shaping of Australia's Labour Market: Conflicting Ideologies of Historical Imperatives?' in Christopher Arup et al (eds), Labour Law and Labour Market Regulation (Federation Press, 2006) 322; Anthony O’Donnell and Richard Mitchell, 'Immigrant Labour in Australia: The Regulatory Framework’ (2001) 14(3) Australian Journal of Labour Law 269; Joo-Cheong Tham and Iain Campbell, 'Temporary Migrant Labour in Australia: The 457 Visa Scheme and Challenges for Labour Regulation' (Working Paper No 50, Centre for Employment and Labour Relations Law, The University of Melbourne, March 2011); Guy Mundlak, 'Recommodifying Time: Working Hours of “Live-In” Domestic Workers' in Joanne Conaghan and Kerry Rittich (eds), Labour Law, Work and Family (Oxford University Press, 2005) 125.

32 Tham and Campbell, 'Temporary Migrant Labour in Australia', above n 31, 37; Joo-Cheong Tham and Iain Campbell, 'Equal Treatment for Temporary Migrant Workers and the Challenge of Their Precariousness' (Paper presented at ILERA (IIRA) $16^{\text {th }}$ World Congress, July 2012) 18-19 <http://www.ilera2012.wharton.upenn.edu/RefereedPapers/ThamJoo CheongIainCampbell.pdf $>$. 
by law at each stage of the migration process. ${ }^{33}$ Many of these factors are tied to what Tham and Campbell (in Australia) and Goldring, Berinstein and Bernhard (in Canada) refer to as 'precarious migration status'. ${ }^{34}$ As noted by Tham and Campbell, for temporary migrant workers, 'their precarious migration status is inextricably linked to a risk of precarious employment'. ${ }^{35}$ While a comprehensive examination of the many interactions between migration and labour laws governing the CSAWP and ASWP is beyond the scope of this article, it will focus on one prominent interaction: that between the seasonal work visa and the accrual of security of employment rights and protections at law.

\section{The IN/SECURITY OF TEMPORARY MigRANT AgRICULTURAL WORK}

\section{A How is Security of Employment Legally Regulated in Canada and Australia?}

The legal rights and protections governing the ease with which workers may be dismissed may be derived from a wide range of training, retention, work sharing and consultation provisions contained in a variety of legal sources. ${ }^{36}$ However, the analysis in this article will focus on three of the most commonly recognised labour law aspects of security of employment present in both countries: (i) notice of termination, (ii) unfair dismissal protections ${ }^{37}$ and (iii) recall rights, broadly construed. It is important to note that while each of these mechanisms plays a role in governing the ease of dismissal, they have different focuses and rationales and play different roles within the overall system of labour law protection in each country. A brief explanation of the differing legal framework in each country is therefore required by way of background.

${ }^{33}$ Fay Faraday, Made in Canada: How the Law Constructs Migrant Worker Insecurity (September 2012) Metcalf Foundation $7<$ http://metcalffoundation.com/wp-content/uploads /2012/09/Made-in-Canada-Full-Report.pdf $>$.

${ }^{34}$ Tham and Campbell, 'Equal Treatment', above n 32, 17 citing Goldring, Berinstein and Bernard, above n 12, 239.

${ }^{35}$ Tham and Campbell, 'Equal Treatment', above n 32, 19.

${ }^{36}$ Steffen Lehndorff and Thomas Haipeter, 'Negotiating Employment Security: Innovations and Derogations' in Susan Hayter (ed), The Role of Collective Bargaining in the Global Economy: Negotiating for Social Justice (Edward Elgar, 2011) 20.

37 Joo-Cheong Tham, 'Job Security Laws: Constituting "Standard" and "Non-Standard" Employment' in Christopher Arup et al (eds), Labour Law and Labour Market Regulation (Federation Press, 2006) 657, 659. 
Notice of termination traditionally derives from the law of contract, which focuses solely on whether sufficient contractual notice of the impending termination (or payment in lieu thereof) is given by the employer to the worker, rather than whether the termination itself was fair. ${ }^{38}$ This classical contractual method of lessening the insecurity of employment applies in Canada, where notice requirements are established by individual contract and by employment standards legislation, which operates to set a floor to reasonable notice entitlements. ${ }^{39}$ Similarly, in Australia, notice of termination is governed by the contract of employment and a floor is set by the National Employment Standards ('NES'), the modern award or, alternatively, in enterprise agreements. ${ }^{40}$

In Australia, the common law protections were supplemented by legislation, and an additional and stronger level of protection against unfair dismissal was created. In Australia, unfair dismissal legislation protects eligible nonprobationary employees (whether unionised or not) against dismissal that is 'harsh, unjust or unreasonable' ${ }^{41}$ and offers either reinstatement or capped damages as a legislated remedy. ${ }^{42}$ Enterprise agreements may not vary the rights or procedures enshrined in the unfair dismissal provisions of the Fair Work Act (' $F W A$ '), although they may create termination procedures to be followed by employers. ${ }^{43}$ By contrast, in Canada, in most jurisdictions, no such unfair dismissal legislation has been enacted. Instead, unfair dismissal rights and protections are generally left to unions to negotiate by way of collective agreements, the status and creation of which are governed by labour relations legislation. ${ }^{44}$ Such agreements protect non-probationary employees in certified (that is, unionised) bargaining units against dismissal except for 'just cause', subject to a right to reinstatement or a substituted lesser discipline ordered by a private grievance arbitrator. ${ }^{45}$

In sectors with varying levels of production (such as manufacturing), both Australian and Canadian labour law also recognises 'recall rights' for workers laid off or stood down due to temporary lack of work. Recall to work is often governed by the concept of seniority (the 'first in, last out' principle) and legal

\footnotetext{
${ }^{38}$ Owens, Riley and Murray, above n 4, 481-2.

${ }^{39}$ Rita Mason, Janine Truelove and Carol Dakai (eds), The Canadian Master Labour Guide (CCH Canada, $22^{\text {nd }}$ ed, 2008) 373-4.

${ }^{40}$ Andrew Stewart, Stewart's Guide to Employment Law (Federation Press, $3^{\text {rd }}$ ed, 2011) 2903.

${ }^{41}$ FWA s 385(b).

${ }^{42}$ Ibid s 390.

${ }^{43}$ Stewart, above n 40, 297; FWA s 194.

${ }^{44}$ Labour Relations Code, RSBC 1996, c-244 ('BCLRC').

${ }^{45}$ BCLRC s 89.
} 
continuity of the employment relationship is preserved. Employment standards legislation in Canada recognises periods of 'temporary lay-off' during which the employment relationship is maintained for the purposes of minimal statutory entitlements, so long as the worker is recalled to work within various specified periods of time. ${ }^{46}$ Seniority-based recall rights are also commonly included in collective agreements, which then supplant the minimum employment standards. ${ }^{47}$ The Australian FWA also reflects the concept through 'stand-down' protections, where legal continuity of employment is preserved ${ }^{48}$ when the 'employee cannot usefully be employed' because of 'a stoppage of work for any cause for which the employer cannot reasonably be held responsible'. ${ }^{49}$ Alternatively, the FWA provision will not apply where the issue of stand-down is addressed by an enterprise agreement or individual contract. ${ }^{50}$ This article therefore adopts a wide definition of 'recall rights' as legally protected exceptions to the wages/work bargain resulting from a temporary downturn in work, where the employee is entitled to return to his or her previous position once work again becomes available.

One problem with the Canadian model of security of employment is that the existence of unfair dismissal protections and recall rights (beyond statutory 'temporary lay-off' provisions) generally depends upon successful enterprise level collective bargaining. In the Canadian agricultural sector, union density (which in Canada is largely synonymous with collective agreement coverage) is just 5.25 per cent. ${ }^{51}$ Agriculture has long been subject to sectoral exclusion from collective bargaining legislation of general application (as it still is in Ontario and Alberta) and other labour law legislation. ${ }^{52}$ Even in provinces that do provide agricultural workers with collective bargaining rights, agreement coverage remains very low for a variety of reasons. Chief among these is the fact that Canada's predominant Wagner $A c t^{53}$ model of collective bargaining generally requires a union to successfully demonstrate majority support before the union obtains bargaining rights with respect to workers in the enterprise level 'bargaining unit' ${ }^{54}$ Such a model is ill-suited to the precarious labour

\footnotetext{
${ }^{46}$ Mason, Truelove and Dakai, above n 39, 382, 391.

${ }^{47}$ Ibid 383; Faraday, above n 33, 40.

${ }^{48}$ FWA s 22(2)(ii).

${ }^{49}$ FWA s 524(1).

${ }^{50}$ FWA s 524(2).

${ }^{51}$ Eric Tucker, 'Farm Worker Exceptionalism: Past, Present, and the Post-Fraser Future' in Fay Farady, Judy Fudge and Eric Tucker (eds), Constitutional Labour Rights in Canada: Farm Workers and the Fraser Case (Irwin Law, 2012) 30, 51-2.

52 Ibid 35-7.

53 National Labor Relations Act of 1935, 29 USC.

${ }^{54}$ Mason, Truelove and Dakai, above n 39, 812-13.
} 
market realities of farm workers generally. ${ }^{55}$ For example, precarious workers themselves often fear employer reprisals for participating in unionisation drives. $^{56}$ In addition, unions lack sufficient resources to certify (that is, 'unionise') small and remote agricultural bargaining units. As a result of Canada's low level of agricultural unionisation and collective bargaining coverage, any examination of security of employment in Canada focuses primarily on the notice of termination provisions contained in a standard form employment contract ('SFEC') that applies to CSAWP workers and on the applicable provincial employment standards legislation. Nevertheless, in this article consideration will also be given to the few innovative collective bargaining agreements concluded with respect to CSAWP workers.

In Australia, by contrast, the focus of this article will be on the safety net and legislative standards generally applicable to agricultural workers, including the Horticulture Award 2010 and the FWA, including the NES and provisions governing unfair dismissal protections and stand-down rights. Interviews conducted by the author, in Australia in August 2012, with unions and government regulators ${ }^{57}$ indicated that although a few enterprise agreements do cover ASWP workers, they do not deviate from the safety net and legislative standards considered in this article. Similarly, individual contracts of employment (which in Australia continue to exist despite the presence of collective industrial instruments) are important to the contractual characterisation of the employment relationship and the legal rights that accompany it (that is, whether the employment relationship is casual or not). However, interviews indicated that, with respect to ASWP workers, such individual contracts were of an oral or minimalist 'letter offer' type. As with enterprise agreements, individual contracts did not deviate from safety net standards contained in the Horticulture Award 2010 and legislation.

\footnotetext{
${ }^{55}$ Tucker, above n 51, 37, 46, 50.

${ }^{56}$ Wayne Hanley, 'The Roots of Organizing Agricultural Workers in Canada' in Fay Faraday, Judy Fudge and Eric Tucker (eds), Constitutional Labour Rights in Canada: Farm Workers and the Fraser Case (Irwin Law, 2012) 59.

${ }^{57}$ Interviews were approved by the Human Research Ethics Committee, University of Melbourne in conjunction with the author's PhD research. Interviews were conducted on an anonymous basis to encourage frank discussion. Interviews were conducted with officials of an Australian governmental labour law enforcement agency on 7 August 2012, and with union officials on 16 August 2012.
} 


\section{B Determining the Applicable Benchmark of Secure Employment for Temporary Migrant Agricultural Workers}

As a starting point, temporary migrant workers are entitled to protections at international law at least as favourable as those enjoyed by local workers. ${ }^{58}$ However, local workers' employment in the agricultural sector is also frequently (though not exclusively) legally insecure, with workers often being employed casually or on fixed-term seasonal contracts. ${ }^{59}$ Comparing one form of legal precariousness against another does not appear to the author to be desirable from a normative perspective. Therefore, this article provides a broader, more conceptually based comparator than a local worker in the same sector. In this regard, the model of the SER (a standard, full-time, ongoing employment relationship with a single employer) is frequently held up as a model of decent work in Canada and Australia. The SER continues to be the regulatory pivot ${ }^{60}$ of both labour law systems, as it attracts the fullest suite of rights and protections. SER employees accrue rights and protections based on increasing length of service and both labour law systems preserve the ongoing nature of the employment relationship despite various protected exceptions to the wages/work bargain, such as temporary lay-off, stand-down, maternity and parental leave, sick leave, carers' leave, and so forth. ${ }^{61}$

The legal precariousness of employment security in both Canada and Australia is best viewed as a continuum of increasingly strong rights and protections, ${ }^{62}$ rather than as a binary model of 'protected' and 'unprotected' employment with defined sets of rights and protections. This is not the case simply because the number of weeks of notice usually increases with service or because employees pass their probationary period and obtain protection against unfair dismissal and recall rights, but also because the nature of those rights and protections becomes increasingly strong. In both Canada and Australia, the interpretation of 'just cause' for dismissal varies with length of tenure of employment. Employees with longer service often benefit from a more protective interpretation of 'just cause' or what constitutes a 'harsh, unjust or unreasonable' termination than those with less service. ${ }^{63}$ Rights to, and the length of, various protected forms of leave also accrue with service.

\footnotetext{
${ }^{58}$ Tham and Campbell, 'Equal Treatment’, above n 32, 7.

${ }^{59}$ John Howe, Andrew Newman and Tess Hardy, Submission of Centre for Employment and Labour Relations Law to the Australian Council of Trade Unions to Independent Inquiry into Insecure Work in Australia (January 2012) Australian Council of Trade Unions 12-16 $<$ http://www.securejobs.org.au/Home/Howe-Inquiry/Submissions.aspx> .

${ }^{60}$ O’Donnell, above n 4, 89.

${ }^{61}$ Kirkpatrick, above n 19, 161-74

${ }^{62}$ Judy Fudge, 'Beyond Vulnerable Workers', above n 14, 158.

${ }^{63}$ Owens, Riley and Murray, above n 4, 493.
} 
Individual rights to be recalled from lay-off or stand down may also strengthen with accrual of seniority.

Due to the privileged role that this continuum of rights and protections gives to length of service as an organising principle, one may ask why temporary migrant workers should be entitled to a comparable level of security of employment as SER employees, given the short-term duration of their employment. Put another way, if it is accepted in principle that security of employment ought to be earned through attachment to a particular employer (which, it should be noted, is far from universally accepted), why should workers hired on fixed-term contracts to meet temporary labour shortages be provided with security of employment? The answer to this question is that the 'temporary' nature of their migration is often constructed by the operation of law rather than by the reality of the employment relationship. ${ }^{64}$ In many cases, employment may more accurately be characterised as an ongoing relationship interrupted by seasonal lay-off and temporary periods of repatriation to the worker's country of origin. Temporary migrant workers therefore often become 'permanently temporary', ${ }^{65}$ meaning that they are unable to obtain permanent residency, regardless of the number of seasons worked in the host country. As noted by Faraday, most CSAWP workers face the prospect of 'perpetual recruitment', whereby employers have absolute discretion regarding whether a worker is rehired in subsequent seasons. ${ }^{66}$ This lack of employment security has been frequently reported to produce high levels of worker vulnerability with respect to their ability to negotiate and enforce workplace rights and entitlements. ${ }^{67}$ By contrast, other temporary migrant worker programs (such as the Live-In Caregiver Program) provide pathways towards permanent residency. ${ }^{68}$ Despite reported difficulties in qualifying for permanent residency, ${ }^{69}$ these programs at least offer the prospect of moving beyond the precariousness of 'permanently temporary' status.

This disconnect between length of service and lack of security is particularly glaring with respect to the CSAWP, which has been operating since 1966, now has approximately 24000 participant workers each year primarily from Mexico and the Caribbean states, ${ }^{70}$ and is generally characterised by a high

\footnotetext{
${ }^{64}$ Faraday, above n 33.

65 Jenna Hennebry, 'Permanently Temporary? Agricultural Workers and Their Integration in Canada’ (2012) 26 IRPP Study 1, 3.

${ }^{66}$ Faraday, above n 33, 74.

${ }^{67}$ Ibid 75.

${ }^{68}$ Ibid 4, 25, 101.

69 Ibid 101.

${ }^{70}$ Ibid 37-43 for further background on the program.
} 
rate of worker return in consecutive seasons. ${ }^{71}$ Lower-end estimates place the number of returning workers at 70 per cent each year. ${ }^{72}$ In a recent study in Ontario by Jenna Hennebrey, the average program service was seven to nine years, with many workers returning to Canada for upwards of 25 years. $^{73}$

The ASWP commenced as the Pacific Island Seasonal Worker Pilot Scheme in August 2008. Only 1623 workers from nine Pacific states were admitted to work for 22 approved employers between February 2009 and September 2012, with the number in 2012 being $1108 .{ }^{74}$ Early indications are that repeat participation is likely to develop. In particular, in one study, 100 per cent of workers surveyed said they wished to return to Australia in subsequent seasons. ${ }^{75}$ Employers have also expressed their desire to hire the same workers in subsequent years. ${ }^{76}$ The evidence from the final evaluation of the Pilot Scheme is that the overall return rate may be substantial, ${ }^{77}$ although the ASWP is in its early stages and any conclusions are therefore necessarily tentative. Nevertheless, as with the CSAWP, participation in the ASWP is not a pathway to permanent residency. ASWP workers, like their CSAWP comparators, also therefore bear the risk of becoming 'permanently temporary'.

Therefore, if it is assumed that the legal rights and protections governing security of employment ought to increase with length of service as they do with SER workers, temporary migrant agricultural workers under the CSAWP and ASWP ought to have their non-continuous length of service recognised at law in order to achieve the same or similar rights and protections as SER workers with a similar length of continuous service. There are several

${ }^{71}$ See, eg, B159/2008 (Sidhu \& Sons Nursery Ltd and United Food and Commercial Workers, Local 1518) [2008] BCLRB (14 October 2008) [17] ('Sidhu').

${ }^{72}$ See, eg, 467 (Travailleurs et travailleuses unis de l'alimentation de du commerce, section locale 501 c La Légumière Y C inc) [2007] QCCRT (24 September 2007) [19] ('TUAC c La Légumière').

${ }^{73}$ Hennebry, above n 64, 13.

${ }^{74}$ Department of Education, Employment and Workplace Relations ('DEEWR'), Pacific Seasonal Worker Pilot Scheme Date Summary (7 January 2013) Department of Employment $<$ http://employment.gov.au/pacific-seasonal-worker-pilot-scheme>.

75 John Gibson and David MacKenzie, 'Australia’s Pacific Seasonal Worker (PSWPS): Development Impacts in the First Two Years' (Working Paper in Economics No 09/11, Department of Economics University of Waikato, June 2011) 17.

${ }^{76}$ ABC Radio, 'Reassigned Tongan Guest Workers Upset Local Balance', Pacific Beat, 4 June 2009 (Alf Fangaloka) <http://www.radioaustralia.net.au/international/radio/onairhighlights /reassigned-tonga-guest-workers-upset-local-balance>.

${ }^{77}$ DEEWR, above $\mathrm{n}$ 73. Of the 1623 total workers, 280 returned for a second season, 45 for a third and 12 for a fourth. While this number seems low, 1108 arrived in the final year of the program (2012). Therefore, of the 515 workers who participated in years where a return to Australia was possible (ie 2009-2011), 280 returned for at least a second year. 
normative arguments to support this reasoning. First, such reforms would promote the consistent application of labour laws, which would have two principal benefits. Consistency would discourage employer regulatory avoidance through reliance upon the lesser legal rights and protections of 'permanently temporary' workers. It would also acknowledge the reality of what are often, in fact if not law, long-term employment relationships deserving of protection. Second, such an expansion of rights and protections would reward the long-term commitment of many CSAWP and ASWP workers to their employers, which in turn would facilitate employer retention of a trained and skilled agricultural work force. This latter goal is particularly important from an employer perspective, given that the need for such programs is often justified by employers on the basis of a domestic labour shortage of trained and reliable agricultural workers. ${ }^{78}$

\section{The CSAWP and the Legal Regulation of Security of Employment}

\section{The Migration Law Parameters of the CSAWP - Understanding the Seasonal Visa}

In Canada, the general power to issue temporary work visas derives from the Immigration and Refugee Protection Act ('IRPA') ${ }^{79}$ and IRPA Regulations. ${ }^{80}$ One of the key immigration objectives of the IRPA is to 'facilitate the entry of ... temporary workers'. ${ }^{81}$ All foreign nationals entering Canada on a temporary basis must satisfy an immigration officer from Citizenship and Immigration Canada that they hold a valid visa and will leave Canada upon expiry of their temporary resident status. ${ }^{82}$

The guiding principles of CSAWP are contained in the bilateral administrative Memoranda of Understanding ('MOUs') and accompanying guidelines formed between Canada and the labour supplying states. ${ }^{83}$ The MOUs are significant because they prescribe that workers are to be subject to Canadian

\footnotetext{
${ }^{78}$ See Canadian Horticultural Council, Human Resources (29 October 2013) <http://www. hortcouncil.ca/projects-and-programs/human resourcces.aspx>. See also National Farmers' Federation, Workplace Relations (2013) <http://www.nff.org.au/policy/workplace.html> .

${ }^{79}$ SC 2011, с 27.

${ }^{80} \mathrm{SOR} / 2002-227$.

${ }^{81}$ IRPA s 3(g).

${ }^{82}$ Ibid ss 20(1)(b), 22-4.

${ }^{83}$ B135/2009 (Greenway Farms Ltd and United Food and Commercial Workers International Union, Local 1518) [2009] BCLRB (29 June 2009) [103] ('Greenway'). The MOUs are not publically available; the author has therefore relied on copies reproduced as evidence in labour board decisions.
} 
laws $^{84}$ (including provincial workplace laws of general application) and that employers will sign a copy of an SFEC as a condition of participating in the program, which will itself be 'subject to annual review by both parties and amended after consultation with employer groups in Canada' ${ }^{85}$ The terms of the four SFECs and two transfer agreements vary slightly according to the adhering province and labour supplying state. However, each relates to a range of terms and conditions of employment, including those relevant to termination of employment, namely the duration of engagement and the scope and termination of employment. CSAWP visas are limited to a maximum duration of eight months between 1 January and 15 December of the same year. Within this period, the employer must guarantee a minimum of 240 hours work over a minimum six-week period. The visa duration may be extended beyond the guaranteed minimum however the terms of the SFECs expressly state that they cannot extend beyond eight months and the workers must reside outside of Canada between December 15 and 1 January. ${ }^{86}$ Such extended terms within the eight month parameter of the visa are often set by the SFECs, but these are merely expected dates rather than enforceable commencement and completion dates (see below). Unfortunately, there are no statistical data that the author is aware of assessing or estimating the actual hours worked by CSAWP workers under the visas.

\section{The SFECS - Contractual Notice of Termination}

While it is therefore nowhere legally required by Canadian migration law that a contract of employment cannot operate for an indefinite term (as long as the employee does not reside and work in Canada outside the parameters of his or her work visa), the SFECs are each categorised as fixed-term contracts and imposed as a condition of participation in the program. The vast majority of CSAWP workers are therefore governed by the express and implied terms of these SFECs and employment standards legislation of general application. ${ }^{87}$ These sources offer only minimal legal protection of employment security.

Under the common law of the individual employment contract, where an employee is wrongfully terminated from his or her fixed-term contract (that is, terminated without just cause or the required period of notice), the employee will be entitled to the value of what he or she would have received but for the

\footnotetext{
${ }^{84}$ Ibid [86].

${ }^{85}$ Ibid [105].

${ }^{86}$ See Employment and Social Development Canada, Seasonal Agricultural Worker Program How to Apply (28 October 2012) <http://www.hrsdc.gc.ca/eng/jobs/foreign_workers/ agriculture/seasonal/index.shtml\#tab5> which includes links to the various SFECs and transfer agreements; Faraday, above n 33, 39.

${ }^{87}$ Kinoshita and Nakache, above n 12, 21-2.
} 
wrongful termination. In the case of a fixed-term contract, this value will be either: (i) the value of the remainder of the fixed-term contract if no express period of notice has been stipulated; or (ii) the value of the express fixed-term stipulated in the contract; or (iii) in the case of legal uncertainty as to the fixed-term nature of the contract, the value of any reasonable notice of termination as an implied term of common law. ${ }^{88}$

If the value of reasonable notice governs, CSAWP workers are disadvantaged relative to SER workers with similar amounts of accrued service. Under common law, reasonable notice is calculated based on the age of the employee, the length of continuous service, the skill level of the employee and other factors. ${ }^{89}$ Under the fixed-term SFECs, CSAWP workers cannot accrue continuous service. Also, they tend to be young, at least in their initial years of participation, due to the physical demands of agricultural work. Finally, they are 'unskilled' by the very terms of the program. ${ }^{90}$ The amount of reasonable notice applicable to such workers at common law therefore tends to be low and in any event approaches the level of minimum employment standards.

Regarding the remaining value of the unexpired term of the fixed-term contract, the SFECs act to minimise the period of notice in a number of ways. First, while SFECs operate for a minimum of 240 hours in a six-week period and cannot operate for more than eight months, the period of engagement is limited either from the worker's arrival to the specified termination date or 'until the completion of the work for which he is hired or assigned which ever comes sooner'. ${ }^{91}$ The work to be completed is not defined by the contract. Therefore, the employer could cut short the term of a CSAWP worker's contract by specifying that the work for which the individual worker was hired has been completed. The period of damages would thus be reduced accordingly. In interviews conducted with employer association officials and their counsel in Ontario by the author in August-September 2012, ${ }^{92}$ it was

\footnotetext{
${ }^{88}$ Owens, Riley and Murray, above n 4, 303; Mason, Truelove and Dakai, above n 39, 435-40.

${ }^{89}$ Owens, Riley and Murray, above n 4, 303.

${ }^{90}$ Faraday, above n 33, 41.

91 See, eg, Employment and Social Development Canada, Seasonal Agricultural Worker Program How to Apply: Agreement for the Employment in Canada of Commonwealth Caribbean Seasonal Agricultural Workers in British Columbia - 2014 (September 2013) pt I cl 2 <http://www.hrsdc.gc.ca/eng/jobs/foreign_workers/agriculture/seasonal/sawpcc2014.pdf> (emphasis added).

${ }^{92}$ As noted above, interviews were conducted on an anonymous basis to encourage frank discussion and in accordance with ethics approval from the University of Melbourne. Interviews were conducted with an official of an employer association involved in the administration of the CSAWP on 27 August 2012, an employer association official on 28 August 2012, a labour lawyer representing CSAWP employers on 29 August 2012, union
} 
noted that in the event of layoff the minimum number of hours/duration (240 hours over six weeks) would apply, although any hours above this amount were not guaranteed and were essentially at the employee's risk. All employer association officials, union officials and their counsel who were interviewed therefore agreed that in the event of an early termination, CSAWP workers were entitled only to the balance payable for this minimum fixed term, regardless of the term of engagement.

This interpretation of the SFECs is supported by the express terms governing penalty provisions for the employer's breach of the agreement. Where the employer 'has not satisfied his obligations under this agreement', the contract may be rescinded by the labour supplying state's Government Agent on behalf of the worker only after the Government Agent and Human Resources and Skills Development Canada ('HRSDC') has been consulted and an attempt to locate alternative employment for the worker has been made. If these requirements are met, the employer must pay the worker a sum 'not less than that which the WORKER would have received if the minimum period of employment had been completed'. ${ }^{33}$ While the balance of the remainder of 240 hours/six weeks does provide some protection in the case of early termination, it is also worthy of note that few CSAWP workers would be likely to be engaged on such a short contract given that their employers incur significant transportation expenses in hiring CSAWP workers from Mexico or the Caribbean.

In addition to terms limiting damages payable in the event of an early termination, CSAWP workers are subject to express termination of employment clauses in SFECs outside of British Columbia ('BC') that arguably lower the usual standard for summary dismissal. For example, the Caribbean and Mexico SFECs with other Canadian provinces state that a worker may be terminated beyond the seven- or 14-day trial period for 'noncompliance, refusal to work or any other sufficient reason' ${ }^{94}$ The proper legal construction of this standard, including whether there are implied rights to

officials on 31 August and 26 September 2012, a provincial government labour law regulator on 27 September 2012, labour lawyers representing CSAWP workers on 26 September 2012 and 1 October 2012, and a community organiser active among migrant workers on 2 October 2012.

93 Employment and Social Development Canada, Seasonal Agricultural Worker Program How to Apply: Agreement for the Employment in Canada of Commonwealth Caribbean Seasonal Agricultural Workers in British Columbia - 2014 (September 2013) pt VIII cl 4 $<$ http://www.hrsdc.gc.ca/eng/jobs/foreign_workers/agriculture/seasonal/sawpcc2014.pdf>.

94 See, eg, Employment and Social Development Canada, Seasonal Agricultural Worker Program How to Apply: Agreement for the Employment of Seasonal Agricultural Workers from Mexico - 2013 (2013) pt X cl 1 <http://www.hrsdc.gc.ca/eng/jobs/foreign_workers /agriculture/seasonal/sawpmc2013.pdf $>$ (emphasis added). 
procedural fairness in the manner of termination, is currently before the Ontario Superior Court. ${ }^{95}$ However, this clause arguably modifies the common law standard of just cause and substitutes a much lower standard of protection against summary dismissal. ${ }^{96}$ Summary dismissal (that is, termination without reasonable notice) in both Canada and Australia would usually only be justified at law where the employee had committed a serious breach of the contract of employment. Examples of such a serious breach would often include theft from one's employer, workplace violence or, as noted in the above SFEC clause, non-compliance with a reasonable employer order or refusal to work. ${ }^{97}$

\section{Employment Standards - Statutory Notice of Termination}

While the temporary work visa and fixed-term SFEC are linked together by the terms of the CSAWP, the MOUs are clear that labour laws of general application, including employment standards legislation, also apply to CSAWP workers. How do these sources of law govern security of employment? An examination of employment standards legislation in BC demonstrates CSAWP workers are disadvantaged by their lack of continuous service.

In the BC Employment Standards Act ('BC ESA') ${ }^{98}$ employers are not required to provide notice of termination or pay in lieu thereof if 'the employee is employed for a definite term' or if 'the employee is hired for specific work to be completed in 12 months of less', unless the 'definite term or specific work is extended for at least three months past its scheduled completion' or it is 'impossible to perform the work because of some unforeseeable event or circumstance (other than bankruptcy, receivership or insolvency)'. ${ }^{99}$ Given the wide latitude of employers under the SFECs to unilaterally determine the length of the contract and the current maximum

\footnotetext{
95 Andrew Lokan and Michael Fenrick, ‘Statement of Claim’ (17 November 2011) in Espinoza $v$ Tigchelaar Berry Farms Inc Ontario Superior Court of Justice, Court File No CV-11439746 (17 November 2011) UFCW Canada [1] <http://www.ufcw.ca/templates/ufcwcanada/ images/directions11/nov/1148/statement_of_claim.pdf> ('Espinoza').

${ }^{96}$ Interview with anonymous union counsel (Ontario, 26 September 2012 and BC, 1 October 2012 (but not counsel for Espinoza) support this interpretation.

${ }^{97}$ Stewart, above n 40, 293-4; Owens, Riley and Murray, above n 4, 302; Mason, Truelove and Dakai, above n 39, 428-32.

${ }^{98}$ Employment Standards Act, RSBC 1996, c 113, s 65(1). The Ontario Employment Standards Act, 2000, SO 2000, c 41 also largely replicates this model of exclusion. However, for the sake of brevity, a detailed consideration of the provisions of that Act are beyond the scope of the article.

${ }^{99}$ BC ESA s 65(1).
} 
eight-month fixed-term, CSAWP workers cannot qualify for statutory notice of termination.

Even if the CSAWP workers were not excluded from coverage, notice of termination under employment standards legislation would be limited by the fixed-term SFECs in other ways. The ESA permits accrual of entitlements to notice of termination based on periods of consecutive service only, which are not severed by periods of legislated 'temporary lay-off' (defined, with certain specified variations, as 13 weeks within a 20 -week period or a period of recall specified in a collective agreement). ${ }^{100}$ Therefore, even if they were covered by the notice provisions contained in the ESA, CSAWP workers would never be able to obtain more than the one week of notice (based on periods of service of more than three consecutive months and less than one year). The period of statutory temporary lay-off for a non-collective agreement covered worker would also be insufficient to preserve employment by bridging the minimum four month gap required between periods of work in Canada. It is also of note that the many CSAWP workers who are employed for the minimum 240 hours/six-week period under the SFEC would be unable to meet the minimum requirement of three consecutive months of probationary service and therefore would not be entitled to any statutory notice of termination. ${ }^{101}$

\section{Collective Agreements - Unfair Dismissal and Recall Rights}

In stark contrast to the terms of the SFEC and employment standards legislation discussed above, various collective agreements covering CSAWP workers recognise accrual of security of employment rights and protections on a non-continuous seasonal basis, subject to the parameters of the CSAWP and compliance with applicable migration laws. The United Food and Commercial Workers ('UFCW') has negotiated a number of such innovative collective agreements covering CSAWP workers in provinces that permit collective bargaining in the agricultural sector. In Mayfair (Manitoba), Floralia, Greenway, Sidhu (BC) and in a number of enterprises in Quebec, the agreements negotiated provide/provided CSAWP workers with recognition of their non-continuous service in a way that formally overcomes the limited duration of the work visa.

While the exact details of each agreement differ, there are a number of similar features. First, service is deemed to accrue on a non-continuous basis

\footnotetext{
100 Ibid ss $1,67(1)$.

101 Ibid s 63.
} 
according to the number of hours or days worked at the enterprise. ${ }^{102}$ Second, probationary periods must be served only once, not in each season. ${ }^{103}$ Third, non-probationary workers obtain the right to expedited grievance arbitration (with union representation) and a decision must be rendered within a matter of days. ${ }^{104}$ Workers dismissed without just cause, as interpreted under arbitral jurisprudence, have the right to reinstatement to their position. Given the particular vulnerability of temporary migrant workers, workers are given the right to continue to reside on the employer's premises until the conclusion of the expedited arbitration. ${ }^{105}$ Fourth, and perhaps most importantly, workers are provided with a right of recall in subsequent seasons based on their noncontinuous service. Employers must request workers to be named to return in subsequent seasons in order of descending seniority, with priority being given to Canadians in accordance with the terms of the CSAWP. ${ }^{106}$

Therefore, while the agreements expressly recognise that they are subject to the migration laws governing the CSAWP, ${ }^{107}$ workers gain security of employment by moving up the continuum of legal rights and protections in the same manner as an SER worker. These collective agreements therefore, in effect recognise what amounts to a form of migrant worker leave - a period of legally protected lay-off coinciding with mandatory repatriation during which time the employment relationship is preserved. These rights are further buttressed by unfair dismissal protections contained in the collective bargaining agreement, which recognise the unique employment relationship of CSAWP workers.

Despite a number of problems related to the certification of CSAWP bargaining units, the resistance of decertification efforts (that is, de-unionising the enterprise) and the successful negotiation and administration of such collective agreements in the first place, ${ }^{108}$ these agreements point to various

\footnotetext{
102 See, eg, Agreement between Mayfair Farms Portage (Ltd) and the United Food and Commercial Workers (expiry date 21 April, 2011) cl 7.

${ }^{103}$ Ibid cl 5.

${ }^{104}$ Ibid cl 14.03(a).

${ }^{105}$ Ibid cl 14.03(b).

${ }^{106}$ Ibid cl 7.03.

107 Ibid cl 4.01.

108 See, eg, 595/06/LRA (United Food and Commercial Workers Union, Local 832 and Mayfair Farms (Portage) Ltd) [2007] MLRB (26 June 2007); Sidhu [2008] BCLRB (14 October 2008); Greenway [2009] BCLRB (29 June 2009) [104]; TUAC c La Légumière [2007] QCCRT (24 September 2007) [19]; B28/2012 (Certain Employees of Sidhu and Sons Nursery Ltd and Certain Employees of Floralia Plant Growers Ltd and Sidhu and Sons Nursery Ltd and Floralia Plant Growers Ltd and United Food and Commercial Worker International Union Local 1518 and United Mexican States and Consulado General de Mexico en Vancouver) [2012] BCLRB (1 February 2012); B194/2012 (Certain Employees of
} 
innovative ways in which security of employment rights and protections could be strengthened for temporary migrant agricultural workers.

\section{The ASWP and the Legal Regulation of Security of Employment}

\section{The Parameters of the ASWP - Understanding the Seasonal Visa}

The power of the Australian Department of Citizenship and Immigration to issue visas to temporary migrant workers under the ASWP is derived from its general powers under the Migration Act $1958^{109}$ and both general and schemespecific provisions under the accompanying Migration Regulations $1994{ }^{110}$ The Migration Act stipulates that the Minister may grant permission, in the form of a visa, for any non-citizen to travel to and enter Australia and remain in Australia. ${ }^{111}$ Classifications of visas are permitted by the Migration Act, including temporary visas, which permit the holder to remain in Australia either: i) for a specified period, or ii) until a specified event happens or iii) while the holder maintains his or her status. ${ }^{112}$ The Migration Act stipulates that the Regulations may specify conditions attaching to visas, ${ }^{113}$ including restrictions as to the 'work that may be done in Australia by the holder'. ${ }^{114}$ At the time that research relevant to this article was concluded in March 2013, the ASWP was governed by a subclass 416 'Special Program Visa' ${ }^{115}$ For a worker to obtain an ASWP visa under subclass 416, the Minister was required to be satisfied that the worker 'seeks to enter Australia to participate in a special program of seasonal work conducted by the special program sponsor in relation to the applicant'. ${ }^{116}$

The administrative details of the ASWP are based on MOUs between Australia and the individual labour supplying states. ${ }^{117}$ With respect to the

Sidhu and Sons Nursery Ltd. and Sidhu and Sons Nursery Ltd. and United Food and Commercial Worker International Union Local 1518 and United Mexican States and Consulado General de Mexico en Vancouver) [2012] BCLRB (21 September 2012).

${ }^{109}$ Migration Act 1958 (Cth) ('Migration Act').

${ }^{110}$ Migration Regulations 1994 (Cth) ('Migration Regulations').

${ }^{111}$ Migration Act s 29.

112 Ibid s 30.

${ }^{113}$ Ibid s 41.

${ }^{114}$ Ibid s 41(2)(b).

${ }^{115}$ Migration Regulations sch 2, cl 416.222.

${ }^{116}$ Ibid cl 416.222(d).

117 See, eg, 'Memorandum of Understanding between the Government of Australia and the Government of the Republic of Kiribati in support of Australia's Pacific Seasonal Worker 
terms and conditions of employment that apply to ASWP workers, the ASWP MOUs contain no standard form employment contracts such as the SFECs and are silent on which labour law instrument ought to apply, other than to mention the application of relevant Australian 'industrial instruments, 118 contained in the MOUs. Other program documents, such as the Expression of Interest to become an Australian Approved Employer for the Seasonal Worker Program, also note that Australian workplace laws are to apply to ASWP workers. $^{119}$

The terms of the ASWP do however prescribe a commitment of a certain number of hours over a certain number of months for all ASWP employers. Currently, approved employers must commit to providing 30 hours a week between 14 weeks and six months. ${ }^{120}$ Visas are issued for seven months within a 12-month period. ${ }^{121}$

\section{The Individual Contract of Employment - Contractual Notice of Termination}

While the individual contract of employment purports to be a fixed-term contract, that fact is by no means clear in practice. Despite the program requiring that 30 hours a week be worked for between 14 weeks and six months (thereby suggesting a fixed term), the contract of employment has also been characterised as 'casual' by various employers. Ball notes that:

The conditions under which seasonal workers in the PSWPS [the ASWP] are employed can vary considerably - by state and by the employment model preference (for example, permanent versus casual contracts) of labour-hire firms that act as the workers' employers. Problems have also arisen due to the differences in the most suitable mechanism. For example,

Pilot Scheme (PSWPS)' (24 November 2008) art 4.t; 'Memorandum of Understanding between the Government of Australia and the Government of the Independent State of Papua New Guinea in support of Australia's Seasonal Worker Pilot Scheme' (8 July 2010) art 3; 'Memorandum of Understanding between the Government of Australia and the Kingdom of Tonga in support of the Australia's Pacific Seasonal Worker Pilot Scheme (PSWPS)' (24 November 2008) art 3.

118 Ibid.

119 Australian Government, Department of Employment, 'Request for Expression of Interest' <http://docs.employment.gov.au/system/files/doc/other/new_reoi_template_-_employment_2 .pdf $>$.

120 Australian Government, Department of Employment, 'Approved Employers Seasonal Worker Program’ <http://docs.employment.gov.au/system/files/doc/other/approved_employer _factsheet_2.pdf $>$.

121 Australian Government, Department of Immigration and Border Protection, 'Special Program Visa (subclass 416) for Seasonal Worker Program' <http://www.immi. gov.au/Visas/Pages/416-SWP.aspx>. 
before the scheme began, the Federal Government negotiated a framework employment agreement with the peak body representing labour-hire firms. Under this agreement, seasonal labourers were to be given all the rights of permanent employees, even though they would be in the country for only seven months. Within one week of the first season (Tongan) workers arriving in Australia, there was discord over the type of employment contract under which the workers were employed ... The first employer of workers under the PSWPS, the Tree Minders labour-hire firm, claimed the 50 Tongans would be employed only as casual workers and if there was no work they would not be paid ... After this, the employment contract was changed to a casual work contract with an average of 30 hours a week guaranteed pay, which would provide the workers higher total wages than if they were under a permanent employment contract. Subsequently, workers under the PSWPS have been employed under permanent and casual work contracts. $^{122}$

The contractual characterisation of some ASWP workers as casual is difficult to reconcile with parameters of the scheme. A casual contract of employment formally arises anew upon each discrete engagement (that is, each separate time the worker performs work) and therefore a worker can be 'dismissed' simply by the employer refusing to re-employ the worker at the next engagement. ${ }^{123}$ However, the policy justification for the ASWP was that the shortage of seasonal workers was sufficiently severe to justify the hiring of workers from outside Australia for an entire season. Nevertheless, perhaps because casual employment offers ASWP workers (who may desire the opportunity to maximise their earnings) a higher hourly wage under the Horticulture Award 2010 than a permanent non-casual worker would receive, ${ }^{124}$ the potential to employ ASWP workers casually is now implied in the Department of Employment application form by which employers express an interest in participating in the program. This form states: 'For example, an Approved Employer in the horticulture industry may nominate to employ workers under (i) the Horticulture Award 2010, and (ii) on a casual rate of pay, at a minimum hourly rate of $\$ 19.49$ '. ${ }^{125}$

This casualisation lessens the security of employment of ASWP workers by denying them the right to seek contractual damages for the unexpired term of

\footnotetext{
${ }^{122}$ Rochelle Ball, 'Australia’s Pacific Seasonal Worker Pilot Scheme and its Interface with the Australian Horticultural Labour Market: Is it Time to Refine the Policy' (2010) 25(1) Pacific Economic Bulletin, 114, 124-5.

${ }^{123}$ Owens, Riley and Murray, above n 4, 186.

${ }^{124}$ See s 14, 'Minimum Wages'.

125 Department of Employment, Seasonal Worker Program: Request for an Expression of Interest (application) to become an Australian Approved Employer for the Seasonal Worker Program (21 October 2013) pt B 'Selection Criteria' (f) p vi <http://employment.gov.au /information-employers-how-recruit-seasonal-workers>.
} 
their contract of employment (that is, the 30 weekly hours for not less than 14 hours and not more than six months). As they are not subject to unfair dismissal protections, AWSP workers who suffer an early termination of their fixed-term contract will only have recourse to courts for breach of contract at common law and will therefore face various obstacles similar to those considered in relation to CSAWP workers. In particular, contractual damages will be limited either to the unexpired period of the short fixed-term contract, or reasonable notice at common law, which itself will be limited by lack of continuous service, the youth of participant workers, and their low levels of formal skill. Interviews conducted by the author with union officials in Australia in August 2012 found that collective bargaining negotiations to date have focused on securing guaranteed hours and duration of work, even though employers have already formally committed to such periods of work as a condition of their participation in the ASWP.

\section{The NES and Modern Award - Statutory Notice of Termination}

With respect to periods of notice of termination under both the NES ${ }^{126}$ and the Horticulture Award 2010, ${ }^{127}$ these sources also tie payments to continuous periods of service at the date of termination. ASWP workers cannot therefore ever accrue more than one week of notice by virtue of the seven month duration of their contractual engagement. They may also be excluded from this entitlement by virtue of being casual workers, ${ }^{128}$ or employed for the duration of a specified time, task or season. ${ }^{129}$

\section{$4 \quad$ Statutory Unfair Dismissal Protections and Recall Rights}

The parameters of unfair dismissal legislation are also tied to the SER continuous service model and act to exclude ASWP workers from coverage regardless of the length of non-continuous service they may have accrued. Under the unfair dismissal provisions of the FWA, employees must have more than six months or 12 months (for small businesses) of continuous service before they obtain protection. ${ }^{130}$ ASWP workers cannot be continuously employed for more than six or 12 months, and therefore cannot satisfy this

\footnotetext{
${ }^{126}$ FWA s 117.

${ }^{127}$ Fair Work, Horticulture Award 2010 (3 April 2009) Australian Government Fair Work Ombudsman s 11 <http://www.fairwork.gov.au/awards/a-z-modern-awards-list/pages/default .aspx\#h>.

${ }^{128}$ FWA s $123(1)(\mathrm{c})$.

${ }^{129}$ Ibid s 123(1)(a).

${ }^{130}$ Ibid ss 383(a)(b), 384(1).
} 
period of service, even if they are employed for multiple consecutive seasons. While local workers are also often exempted by virtue of being seasonal or fixed-term employees who have come to the end of the season, task or term of their contract, ${ }^{131}$ they at least have the possibility of maintaining ongoing status, particularly given the multiple sequential growing seasons in many parts of Australia. Further, even if local workers are not categorised as SER workers, they will still enjoy advantages over ASWP workers. If local seasonal workers serve out the six- or 12-month waiting period they may still apply to the Fair Work Commission for a pay out of the balance of their contract if it is terminated prior to its expiry. ${ }^{132}$ If not re-hired at the end of the contract or at the end of a seasonal or casual contract, the employee could not, of course, be dismissed as their contract has expired. ${ }^{133}$ However, if the local employee is a regular casual worker with a 'reasonable expectation of continuing employment on a regular or systemic basis', he or she could still obtain unfair dismissal protection. ${ }^{134}$ Similarly, a worker on successive rolling contracts may obtain protection if the substantial reason for the arrangement is to avoid the application of the unfair dismissal legislation. ${ }^{135}$

By contrast, it could be argued that ASWP workers cannot have a reasonable expectation of ongoing employment as their visa requires them to exit the country at the end of the season. However, if the ASWP develops the high rate of worker return currently characterising the CSAWP (where the average tenure of employment is seven to nine years), one might then be able to argue for the existence of a 'reasonable expectation of continuing employment on a regular or systemic basis' despite the worker being required by the temporary nature of the visa to leave Australia during the off-season. Such an approach is consistent with previous tribunal decisions in Australia recognising that the 'reasonable expectation of continuing employment' is framed in part by the nature of the industry and when work is available. ${ }^{136}$ In Canada, the analysis of when work is 'available' to migrant workers has in rare cases gone one step further. In at least one case ${ }^{137}$ it has been held that a temporary migrant worker applying for employment insurance benefits was entitled to benefits because, even though the nature of his work permit would not allow him to accept other employment, he was capable of and available to work. Justice Hadad held, regarding the meaning of 'available' and 'capable', that the exclusion from benefits was 'not intended to apply where unavailability is

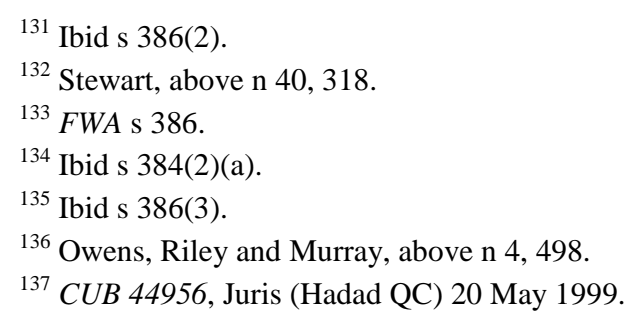


imposed upon a claimant in circumstances beyond his control when the claimant is ready, available, and willing to accept employment. ${ }^{138}$ Under the current state of the law in Australia, however, it appears unlikely that ASWP workers would obtain such a favourable interpretation of the 'reasonable expectations’ provision.

With respect to recall rights following a stand-down, the interviews conducted by the author in August 2012 in Australia indicate that no recall rights of the kind negotiated by the UFCW in Canada currently exist in Australia with respect to ASWP workers. This is not surprising given the small size and recent implementation of the program. The potential to negotiate such clauses is, however, recognised in the FWA, ${ }^{139}$ and will be outlined below.

\section{Concluding Thoughts ANd Possible Options for LEGAL REFORM}

\section{A Legal Reform Options}

While the granting of 'migrant worker leave' would represent a fundamental departure from current practice, there are a number of ways in which it could be extended to CSAWP and ASWP workers, thus preserving the legal continuity of employment.

As noted in Part III C 4 above, collective bargaining represents one potential way to displace the SFEC and overcome the disadvantages associated with the seasonal work visa under the CSAWP. A second option would be to amend the SFEC so that it becomes a contract of indefinite term, subject to the employee passing a single probationary period and complying with all visa and migration law requirements of the CSAWP. All periods of mandatory repatriation could then be contractually classified as unpaid migrant worker leave in the same way as other forms of recognised leave frequently available to SER employees (annual leave, carer's leave, education leave, and so forth). Seasonal, non-continuous service would thus be expressly counted towards the accrual of notice of termination entitlements and/or a right to be recalled in accordance with seniority measured on a non-continuous basis. ${ }^{140}$ As long as the contract does not stipulate that the worker enter, reside and work in Canada without a work visa, it does not directly conflict with the migration

\footnotetext{
${ }^{138}$ W J Haddad, CUB 44956 (27 April 1999) Service Canada <http://www.ei.gc.ca/eng/policy /appeals/cubs/40000-50000/44000-44999/44956.shtml> .

${ }^{139}$ FWA s 524.

${ }^{140}$ Faraday, above n 33, 40 and accompanying n 93.
} 
law parameters of the program. In fact, the practice of negotiating contracts within a migration law framework is common in other industries, where highly skilled employees sign contracts conditional on the lawful acquisition and maintenance of a visa. It is also reflective of the terms of the UFCW collective agreements considered above.

Another key manner in which the security of employment of CSAWP workers is regulated is via employment standards legislation. As noted above, such legislation currently prevents seasonal CSAWP workers from accruing rights and entitlements. By contrast, in the Canadian province of Manitoba, the Employment Standards Code ${ }^{141}$ provides relatively innovative and favourable entitlements to all seasonal agricultural workers by permitting the accrual of notice of termination entitlements on a non-continuous basis. ${ }^{142}$ Further options available under Canadian employment standards legislation would be to extend the definition of 'temporary lay-off' or other recognised leave to preserve the continuous employment relationship. Again, there is no reason why mandatory repatriation of CSAWP workers could not be reconceptualised as a form of unpaid leave, thus preserving continuity of the employment relationship.

In Australia, the most direct option for reform would be for the Commonwealth government to impose a standard form contract as a condition of participation in the program with wording similar to that noted immediately above, that is, an ongoing contract with protection of unpaid migrant worker leave. It could thus overcome continuous service requirements contained in the Horticulture Award 2010 and NES, including those applying to casual, fixed-term and seasonal employment. With respect to unfair dismissal protections, the term 'reasonable expectation of continuing employment' in the FWA could be expressly amended to cover non-continuous ASWP workers employed in consecutive seasons for the same employer. The FWA currently recognises that continuous employment is not broken by certain unpaid 'excluded periods', ${ }^{143}$ including community leave, ${ }^{144}$ a stand down that applies under an enterprise agreement or contract of employment or 'a period of leave or absence of a kind prescribed by the regulations'. ${ }^{145}$ The regulations could thus be amended to reflect this period of mandatory unpaid migrant worker leave. Alternatively, contracts or enterprise agreements could be

\footnotetext{
${ }^{141}$ Employment Standards Code, CCSM, c E110.

${ }^{142}$ Manitoba Family Services and Labour, A Guide to Employment Standards in Agriculture (22 August 2013) <http://www.gov.mb.ca/labour/standards/doc,guide-agriculture,factsheet. html\#q852>.

${ }^{143}$ FWA s 22(3).

${ }^{144}$ Ibid s 22(2)(b)(i).

${ }^{145}$ Ibid s 22(2)(b)(iii).
} 
negotiated to utilise the 'stand down' exception during mandatory seasonal repatriation of ASWP workers in a manner similar to the recall provisions in the Canadian UFCW agreements. While the recognition of the legal continuity of employment for seasonal workers may amount to a fundamental reform, it is worth noting that the benefits of other labour law legislation in Australia, such as long service leave, already expressly extend to seasonal workers in certain cases, regardless of what other employment activities the seasonal worker engages in during the off-season. ${ }^{146}$ Similarly, other labour law rights and entitlements have been extended to cover fixed term, seasonal or non-standard engagements. For example, in the Victorian building and construction sector, industry-wide funds for redundancy pay, sick leave and income support, and to support trauma schemes, currently exist. These funds permit employees with non-consecutive employment to accrue rights and entitlements, regardless of the non-continuous, project-to-project basis of their employment. ${ }^{14}$

\section{Conclusion}

Despite markedly differing labour law systems and program structures, both CSAWP and ASWP workers possess minimal legal rights and protections with respect to notice of termination, unfair dismissal and recall rights. These disadvantages are due in part to the fixed-term nature of their employment. Under the current law, an employer may dismiss a temporary migrant agricultural worker regardless of the length of that worker's non-continuous seasonal service. However, while it is often assumed that this must necessarily be the case given the fixed-term duration of the work visa, there is no reason at law why labour law rights and protections could not be re-conceptualised to recognise non-continuous service within the parameters of each program. This could be accomplished in both countries by utilising individual contracts, collective industrial instruments and legislation to recognise a form of migrant worker leave. Such measures would preserve the legal continuity of service among ASWP and CSAWP workers and allow the accrual of rights and protections commonly enjoyed by SER workers with similar periods of continuous service.

\footnotetext{
${ }^{146}$ Long Service Leave Act 1992 (Vic) 62A.

${ }^{147}$ Incolink, 'Home’ (2011) <http://www.incolink.org.au/Out-of-Work-Benefits.aspx>.
} 
